\title{
Intracellular distribution of 3,6-bis(3-alkylguanidino)acridines determines their cytotoxicity
}

\author{
L. KRAJNAKOVA ${ }^{1}$, H. PAULIKOVA ${ }^{1}$, Z. BACOVA ${ }^{2}$, J. BAKOS ${ }^{2}$, L. JANOVEC 33 , J. IMRICH ${ }^{3}$, L. HUNAKOVA $4, *$ \\ ${ }^{1}$ Department of Biochemistry and Microbiology, Faculty of Chemical and Food Technology, Radlinskeho 9, 81237 Bratislava, Slovakia; ${ }^{2}$ Institute \\ of Experimental Endocrinology, Slovak Academy of Sciences, Vlarska 3, 81237 Bratislava, Slovakia; ${ }^{3}$ Department of Organic Chemistry, Institute \\ of Chemistry, Faculty of Science, P.J. Safarik University, Moyzesova 11, SK-04167 Kosice, Slovakia; ${ }^{4}$ Cancer Research Institute, Slovak Academy \\ of Sciences, Vlarska 7, 81237 Bratislava, Slovakia
}

*Correspondance: luba.hunakova@savba.sk

Received March 4, 2014 / Accepted August 21, 2014

\begin{abstract}
Cytotoxicity of two derivatives of 3,6-bis(3-alkylguanidino)acridines (GNDAs; pentyl- and hexyl-GNDA) was determined against three cell lines: a murine immortalized fibroblast cell line NIH-3T3, a human ovarian carcinoma cell line A2780, and a human neuroblastoma cell line SH-SY5Y. We found out that these GNDAs were cytotoxic against A2780 and NIH-3T3 cells but they showed only a marginal cytotoxicity against neuroblastoma cells SH-SY5Y. To explain differences in cytotoxicity, intracellular distribution of GNDAs was monitored. GNDAs were accumulated in A2780 and NIH-3T3 cells in the nuclei (fluorescence microscopy). In contrast to these cell lines, in SH-SY5Y cells, GNDAs were localized outside of the nuclei, at the plasma membrane and surroundings, extending also to the cytosol. This distribution of GNDAs was confirmed by an ImageStream Flow Cytometer. Acetylcholinesterase (AChE) activity in the SH-SY5Y cells decreased upon incubation with GNDAs. Kinetic studies showed that GNDAs were able to inhibit AChE by the same mode as tacrine (9-amino-1,2,3,4tetrahydroacridine), a known inhibitor of AChE. A low cytotocity of GNDAs against SH-SY5Y cells could be caused by their affinity to AChE (the enzyme is localized mainly at the plasma membrane). The interaction of GNDAs with AChE may affect their intracellular distribution and consequently the cytotoxicity.
\end{abstract}

Key words: acetylcholinesterase, acridine, neuroblastoma cell line SH-SY5Y

DNA represents an important target for some of the established and new anticancer drugs [1-6]. Among these, derivatives of acridine have shown a high anticancer activity. Amsacrine and its analogues belong among the most tested acridine drugs used in antitumor therapy [7-9]. Cytotoxicity of these drugs is associated with their DNA binding activity, whereby most of them act as inhibitors of topoisomerases or DNA intercalators [10]. The search for novel anticancer drugs encouraged the preparation of many sets of new acridine derivatives [11-15]. A number of novel acridine derivatives have been prepared in our laboratory and their interaction with DNA and in vitro anticancer activity have been studied $[9,10]$. Recently, Plsikova et al. [16] studied 3,6-bis(3-alkylguanidino) acridines (GNDAs), the new guanidine derivatives based on proflavine, which possess symmetrical, extending alkyl chains (alkyl-GNDA, Fig. 1). These substances have a strong DNA binding activity and these with penty- and hexyl- alkyl chains also a high cytotoxicity, leading to apoptosis of HL-60 leukemia cells [16].

The purpose of this study was to investigate cytotoxicity of the GNDAs to other neoplastic cell lines and the factors which could influence effects of these compounds. In particular, an intracellular distribution of GNDAs in the cells was a main object of our interest.

\section{Materials and methods}

Chemicals. All chemicals and reagents were purchased and used without further purification. $\mathrm{Na}_{2} \mathrm{HPO}_{4} \cdot 12 \mathrm{H}_{2} \mathrm{O}, \mathrm{KH}_{2} \mathrm{PO}_{4}$, and $\mathrm{NaCl}$ were obtained from Lachema (Czech Republic), FBS (fetal bovine serum), DMEM (Dulbecco's Modified Eagle's Medium), HAM F12 (Ham's Nutrient Mixture F12), RPMI 1640, propidium iodide, PBS (Phosphate Buffered Saline), trypsin, DMSO (dimethyl sulfoxide), tacrine, and 
MTT (3-(4,5-dimethylthiazol-2-yl)-2,5-dimethyl tetrazolium bromide) from Sigma-Aldrich Chemie (Germany), paraformaldehyde from Merck KGaA (Germany), and Triton X-100 (100\%) from Serva (Germany).

3,6-Bis(3-alkylguanidino)acridine hydrochlorides (Fig. 1 , GNDAs) were synthesized in the Department of Organic Chemistry, Faculty of Science, University in Kosice as hydrochloride salts [16].

Cell cultures and treatments. The murine immortalized fibroblast cell line NIH-3T3 was obtained from the American Type Culture Collection, Rockville, MD (USA). The cells were routinely cultured in DMEM supplemented with $10 \%$ FBS, $2 \mathrm{mM} \mathrm{L}$-glutamine, penicillin $(100 \mathrm{U} / \mathrm{mL})$, and streptomycin $(100 \mu \mathrm{g} / \mathrm{mL})$. The human ovarian carcinoma cells A2780 were grown in the RPMI 1640 medium supplemented with $10 \%$ FBS, penicillin $(100 \mathrm{U} / \mathrm{mL})$, streptomycin $(100 \mu \mathrm{g} / \mathrm{mL})$, and with $(2 \mathrm{mM}) L$-glutamine. The human neuroblastoma cell line SH-SY5Y was routinely cultured in a DMEM : Ham F12 medium (1:1) supplemented with $10 \%$ fetal bovine serum (FBS), streptomycin $(100 \mu \mathrm{g} / \mathrm{mL})$, penicillin $(100 \mathrm{U} / \mathrm{mL}), 1 \%$ $L$-glutamine, and $0.1 \%$ non-essential amino acids (all obtained from Sigma-Aldrich Chemie).

The cells were seeded into the tissue culture flasks $(75 \mathrm{~mL})$ containing the supplemented medium and kept in a humidified atmosphere of $5 \% \mathrm{CO} 2$ and $95 \%$ air at $37^{\circ} \mathrm{C}$.

Cytotoxic studies. To evaluate the cytotoxic effect of GNDAs, the cells were seeded in 96-well plates $\left(2.5 \times 10^{4}\right.$ cells/ well, MTT assay) and treated with different concentrations of GNDAs for 24, 48, or $72 \mathrm{~h}$. All experiments were carried out $24 \mathrm{~h}$ (NIH-3T3 and A2780 cells) or $48 \mathrm{~h}$ (SH-SY5Y cells) after the cells were seeded. Control experiments with equivalent volumes of DMSO were carried out.

MTT assay. A cell viability in the presence or absence of the experimental agent was determined using a MTT (3-(4,5-dimethylthiazol-2-yl)-2,5-dimethyl tetrazolium bromide) microculture tetrazolium assay as described previously [17]. After $48 \mathrm{~h}$ exposure to the compound, MTT ( $50 \mu \mathrm{l}, 1 \mathrm{mg} /$ $\mathrm{mL}$ ) was added to each well. After $3 \mathrm{~h}$, the cell cultures were centrifuged, the supernatant discarded, and the resulting pellets thoroughly extracted into $200 \mu \mathrm{L}$ of DMSO. Absorption at $540 \mathrm{~nm}$ was recorded using a MicroPlate Reader (Labsystem Multiscan, Multisoft, Finland).

Intracellular accumulation of GNDA. To investigate the intracellular distribution of GNDAs, the cells were seeded onto a cover slip in $40 \mathrm{~mm}$ Petri dishes. The NIH-3T3, A2780 $\left(1.5 \times 10^{5} / \mathrm{mL}\right)$ and SH-SY5Y $\left(2.5 \times 10^{5} / \mathrm{mL}\right)$ cells were treated with $5 \mu \mathrm{M}$ hexyl-GNDA for $30 \mathrm{~min}$ or $48 \mathrm{~h}$, then washed with sterile PBS, and observed using a fluorescence microscope (Axio Zeiss Imager A1, camera AxioCamMrc, Germany).

Analysis of localization of hexyl-GNDA in the cell nucleus. SH-SY5Y cells were treated with $10 \mu \mathrm{M}$ GNDAs $\left(1 \mathrm{~h}\right.$ or $\left.48 \mathrm{~h}, 37^{\circ} \mathrm{C}\right)$ and then the cells were incubated with $100 \mathrm{nM}$ Syto62Red $\left(35 \mathrm{~min}, 37^{\circ} \mathrm{C}\right)$, a nucleic acids dye. After incubation, the cells were rinsed twice in PBS and immedi- ately visualized using an Amnis ImageStream Imaging Flow Cytometer: hexyl-GNDA (channel 8), Syto62Red (channel 11), VIS (channel 1). Bright Detail Similarity Features were calculated for double positive, single, and focused cell population.

Preparation of human erythrocytes $\mathrm{AChE}_{\mathrm{E}}$. Erythrocytes were isolated from a fresh blood of healthy donors of both sexes (provided by the Hematologic Clinics Ruzinov in Bratislava). The blood was centrifuged $(2500 \times \mathrm{g}, 10 \mathrm{~min})$, the erythrocyte sediment was washed, suspended in the solution $(165 \mathrm{mM}$ $\mathrm{NaCl}$ ), centrifuged at $2500 \times \mathrm{g}$ for $10 \mathrm{~min}$, and the washing was repeated until the supernatant became completely clear. Distilled water was added in the ratio 1:5 and the mixture was incubated $\left(25^{\circ} \mathrm{C}, 90 \mathrm{~min}\right)$. The suspension was centrifuged at $12000 \times \mathrm{g}\left(4^{\circ} \mathrm{C}, 25 \mathrm{~min}\right)$. The sediment was washed three times with distilled water and centrifuged after each washing under the same conditions as above. The Sörensen solution ( $2 \mathrm{~mL}, 0.1 \mathrm{M}, \mathrm{pH} 7.2$ ), $1 \mathrm{~mL}$ of $1 \mathrm{mM}$ EDTA, and 1\% Triton-X 100 were added to the sediment. After 5 min centrifugation at $20800 \times \mathrm{g}$, the sediment was removed and the supernatant was stored at $-20^{\circ} \mathrm{C}$ as a source membrane bound $\mathrm{AChE}_{\mathrm{E}}$ for further use up to 2 weeks [18].

AChE activity. Activity of AChE was determined by an Ellman's method [19] modified by Alhomida et al. [20]. Hydrolysis of acetylthiocholine (ATCh) was monitored at $436 \mathrm{~nm}$ by formation of a 5 -thio-2-nitrobenzoate anion resulting from the reaction of 5,5'-dithio-bis(2-nitrobenzonic acid) (DTNB) with thiocholine that is released from enzymatic hydrolysis of ATCh. The hydrolysis rate was measured in $2 \mathrm{~mL}$ assay solutions with $100 \mathrm{mM}$ phosphate buffer, $\mathrm{pH}$ 7.4, $0.1 \mathrm{mM}$ ATCh, and $0.5 \mathrm{mM} \mathrm{DTNB}$ at $37^{\circ} \mathrm{C}$. Isolated $\mathrm{AChE}_{\mathrm{F}}$ or cell lysate (the SH-SY5Y cells were harvested with a plastic spatula and disintegrated by sonication in $300 \mu \mathrm{L}$ PBS) was added to the reaction mixture and pre-incubated with DTNB for 5 min at $37^{\circ} \mathrm{C}$. Before measuring an absorbance change (a Specord 250 spectrophotometer, Analytic Jena, Germany), the ATCh was added. The hydrolysis of ATCh was monitored for $10 \mathrm{~min}$ and the enzyme activity was calculated from a slope of the obtained linear dependence.

The activities were calculated using a molar absorption coefficient of $11280 \mathrm{M}^{-1} \mathrm{~cm}^{-1}$ [21]. Data were normalized to the amount of protein. Results were presented as a percentage of the activity in untreated cells (as 100\%). The protein content was determined according to a method of Bradford [22].

To study an effect of GNDAs or tacrine on the AChE activity, the enzyme suspension $\left(\mathrm{AChE}_{\mathrm{E}}\right.$ or cell lysate) was pre-incubated with GNDAs or tacrine for $5 \mathrm{~min}$ prior to addition of the substrate. To determine that effect in SH-SY5Y cells (the cells were seeded in $75 \mathrm{~mm}$ Petri dishes, $2 \times 10^{6}$ cells/ dish), the cells were incubated with the substances for $48 \mathrm{~h}$, then were scraped and collected in the phosphate buffer, $\mathrm{pH}$ $7.4(2 \mathrm{~mL})$, after that, the cells were disrupted by freezing and thawing and the cell lysate was and kept on ice and used for determination of the AChE activity. 
<smiles>[R]NC(=N)Nc1ccc2cc3ccc(NC(=N)N[R])cc3nc2c1</smiles>

$2 \mathrm{HCl} .4 \mathrm{H}_{2} \mathrm{O}$

R- n-pentyl, n-hexyl

Figure 1. Chemical structures of tested 3,6-bis(3-alkylguanidino)acridine hydrochlorides.

Kinetic studies. Kinetic studies were performed using an isolated $\mathrm{AChE}_{\mathrm{E}}$. Enzyme activities were determined at $37^{\circ} \mathrm{C}$ with growing acetylthiocholine concentrations $(0.02-$ $0.1 \mathrm{mM})$ in the presence or absence of inhibitors $(0.5-1.5 \mu \mathrm{M})$. Lineweaver-Burk plots were used to reveal a mechanism of inhibition. Replots of the slopes versus the inhibitor concentrations gave estimates of Ki. Graphs were plotted in an Origin Pro 8 program.

Statistical analysis. Results were calculated as a mean \pm standard deviation (S.D.) of at least three independent experiments. Statistical significance was determined by the
Table 1. Cytotoxicity of GNDAs against A2780, NIH-3T3 and SH-SY5Y cells

\begin{tabular}{|c|c|c|c|c|c|}
\hline \multirow[t]{2}{*}{ Cell line } & \multirow[t]{2}{*}{ Compound } & \multirow[t]{2}{*}{$c[\mu \mathrm{M}]$} & \multicolumn{3}{|c|}{ Viability[\%] ${ }^{\mathrm{a}}$} \\
\hline & & & $24 \mathrm{~h}$ & $48 \mathrm{~h}$ & $72 \mathrm{~h}$ \\
\hline \multirow{4}{*}{ A2780 } & Pentyl-GNDA & 10 & $62 \pm 9.8$ & $76 \pm 10.3$ & $66 \pm 12.3$ \\
\hline & & 50 & $51 \pm 10.5$ & $57 \pm 9.5$ & $39 \pm 8.7$ \\
\hline & Hexyl-GNDA & 10 & $46 \pm 9.8$ & $60 \pm 10.8$ & $60 \pm 11.3$ \\
\hline & & 50 & $37 \pm 12.7$ & $38 \pm 8.6$ & $39 \pm 9.6$ \\
\hline \multirow{4}{*}{ NIH-3T3 } & Pentyl-GNDA & 10 & $58.3 \pm 14.2$ & $57 \pm 11.4$ & $46 \pm 10.0$ \\
\hline & & 50 & $35.3 \pm 8.5$ & $46 \pm 9.3$ & $40 \pm 9.8$ \\
\hline & Hexyl-GNDA & 10 & $64 \pm 12.6$ & $54 \pm 11.0$ & $26 \pm 8.0$ \\
\hline & & 50 & $25.5 \pm 14.8$ & $8 \pm 5.7$ & $6 \pm 5.0$ \\
\hline \multirow{4}{*}{ SH-SY5Y } & Pentyl-GNDA & 10 & $88.0 \pm 13.2$ & $84.2 \pm 15.4$ & $84.9 \pm 10.5$ \\
\hline & & 50 & $84.0 \pm 8.7$ & $80.7 \pm 10.8$ & $77.7 \pm 9.4$ \\
\hline & Hexyl-GNDA & 10 & $84.8 \pm 9.7$ & $80.7 \pm 14.2$ & $86.2 \pm 9.8$ \\
\hline & & 50 & $79.5 \pm 9.0$ & $74.9 \pm 9.1$ & $74.9 \pm 7.7$ \\
\hline
\end{tabular}

${ }^{a}$ The results are presented as a mean $\pm \mathrm{SD}(\mathrm{n}=3)$.

Student's $t$ test and $p \leq 0.05$ was taken as the limit of statistical significance.
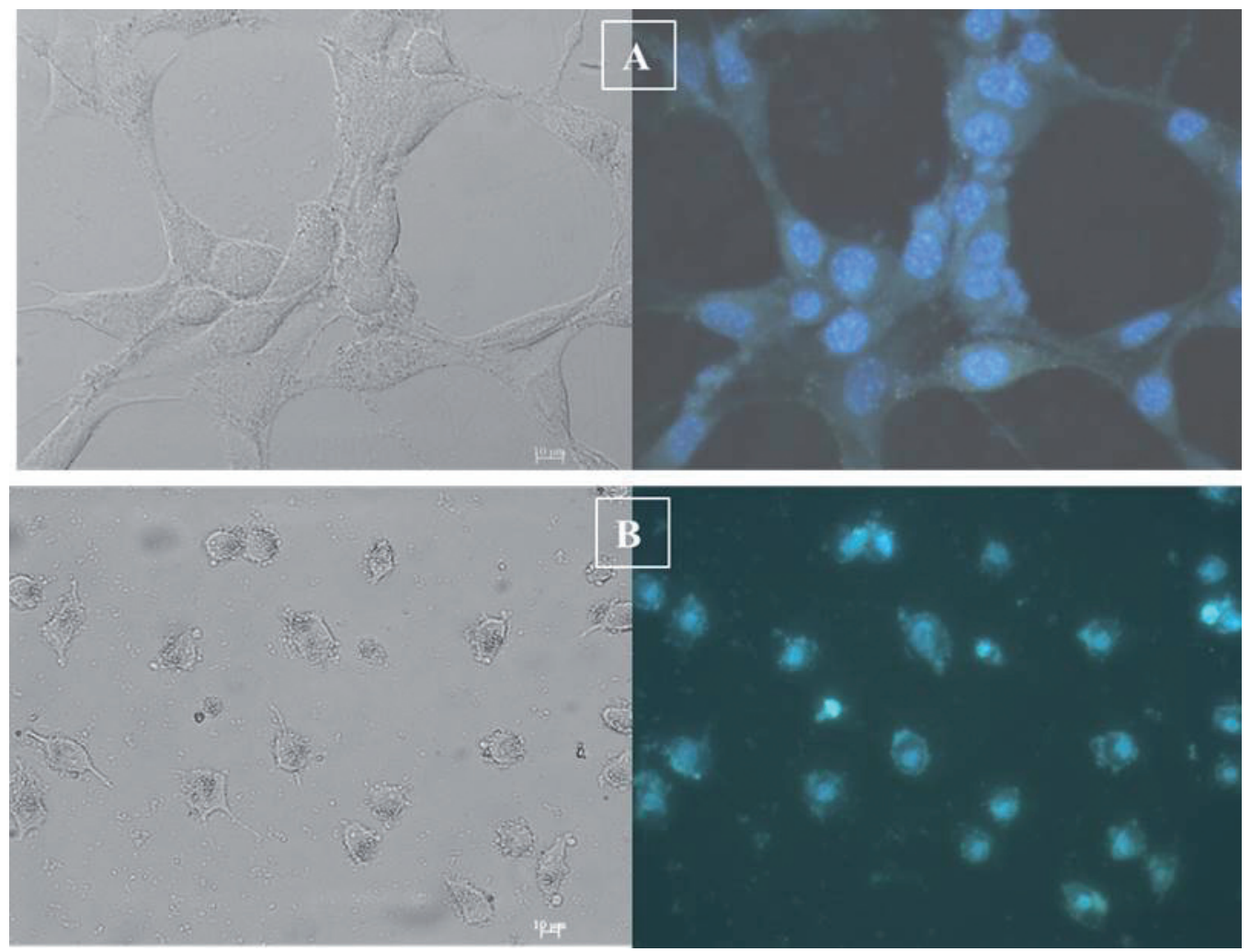

Figure 2. Intracellular accumulation of hexyl-GNDA in NIH-3T3 (A) and A2780 (B) cells visualized by fluorescence microscopy. The cells were incubated with hexyl-GNDA $(5 \mu \mathrm{M})$ for $30 \mathrm{~min}$ and then washed with PBS. Images were obtained by the fluorescence microscope Axio Zeiss Imager A1, camera AxioCam MRc, magnification 630x or 400x. The cells were visualized using a filter with an emission wavelength of $420 \mathrm{~nm}$. Representative images are shown from three independent experiments. 


\section{Results}

Cytotoxicity. We explored the toxicity of two GNDA derivatives, pentyl-GNDA and hexyl-GNDA, against the A2780, NIH-3T3 and SH-SY5Y cells. As can be seen in Table 1, GNDAs markedly decreased viability of A2780 and NIH3 T3 cells. For example the hexyl-GNDA derivative reduced the viability of these cells by 40 and $74 \%$, respectively, after $72 \mathrm{~h}$ treatment in $10 \mu \mathrm{M}$ concentration. However, the toxicity of the both GNDAs against SH-SY5Y cells in the same conditions was very low, when the viability decreased only by $15 \%$.

Intracellular distribution. The cytotoxicity of GNDAs against NIH-3T3 and A2780 cells was much higher than against the neuroblastoma cells SH-SY5Y. Such differences in toxicity may result from a different intracellular distribution of GNDAs. As the both tested analogs showed the same distribution in all cell lines, we will further show the hexyl-GNDA as an example. As shown in Fig. 2 (A, B), the hexyl-GNDA was accumulated in the nucleus and cytosol of the NIH-3T3 or A2780 cells after 30 min incubation. However, in the SHSY5Y cells, we did not observe any nuclear accumulation of GNDAs after short-time (30 min) incubation (Fig. 3A). We checked also their long-term (48 h) distribution in SH-SY5Y cells by fluorescence microscopy, but with the same negative result (Fig. 3B). The cellular sequestration of the hexyl-GNDA on microphotographs (Fig. 3) shows a strong fluorescence signal observed at the plasma membrane of SH-SY5Y cells and surroundings, extending also to the cytosol, but remaining outside of the nucleus.

To confirm localization of the GNDAs outside of the nucleus, an Image stream imaging technique for colocalisation using the Syto62Red nucleic acid dye was applied. As shown in Fig. 4, the fluorescence of hexyl-GNDA and Syto62Red were not overlaid even after long-term incubation. The values of Bright Detail Similarity R3 Feature were below 1.0 and 1.7 after $1 \mathrm{~h}$ and $48 \mathrm{~h}$ incubation, respectively (Fig. 4). The obtained results proved that hexyl-GNDA were not present in the nuclei of SH-SY5Y cells.

Interaction with AChE in SH-SY5Y. Intracellular localization of the hexyl-GNDA outside of the nucleus (Fig. 3 and 4) indicates that this substance has a high affinity to other targets in the SH-SY5Y cells. Considering localization of the GNDA at the plasma membrane, proteins of the plasma membrane could interact with these substances. Based on the literature reports [23] we supposed that acetylcholinesterase (EC 3.1.1.7; AChE) among others could be a cellular target of GNDAs in the SH-SY5Y cells, therefore effects of GNDAs on the enzyme activity in SH-SY5Y cells were investigated and compared to a tacrine (9-amino-1,2,3,4-tetrahydroacridine)


Figure 3. Intracellular distribution of hexyl-GNDA in SH-SY5Y cells. The cells were incubated with the hexyl-GNDA for $30 \mathrm{~min}$ (A) or $48 \mathrm{~h}$ (B), and then washed with PBS. The images were obtained using the same instrument as above in magnification 400x. 

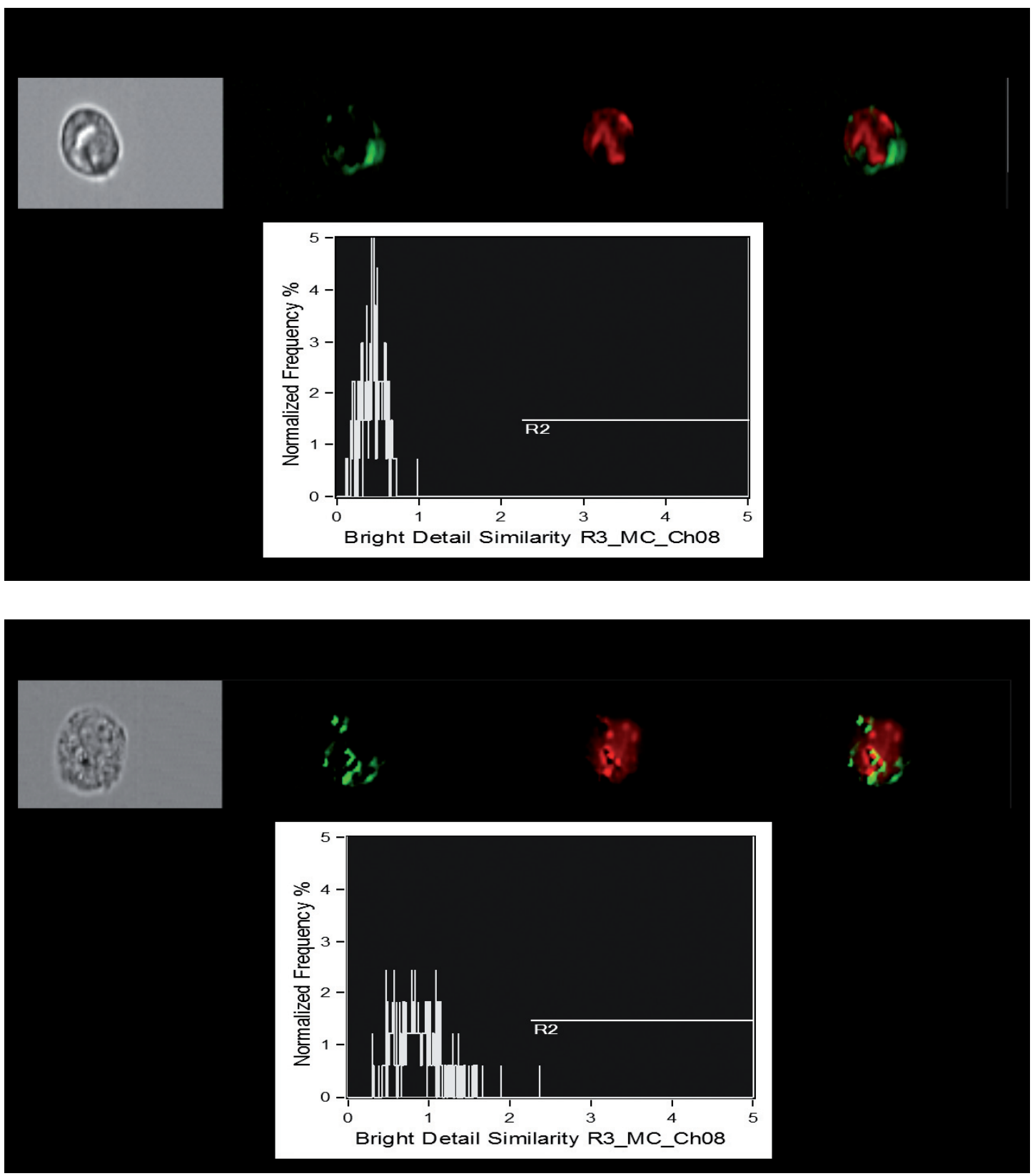

Figure 4. Colocalization of fluorescence of the hexyl-GNDA and Syto62Red nucleic acid dye. SH-SY5Y cells were incubated with the hexyl-GNDA (10 $\mu$, green) for $1 \mathrm{~h} \mathrm{(A)} \mathrm{or} 48 \mathrm{~h}$ (B). After labeling with Syto62Red (100 nM), the cells were analyzed using an Amnis ImageStream Imaging Flow Cytometer. The parameter reflecting the colocalization of two probes, Bright Detail Similarity R3 Feature, was calculated. The resulting values around 1 mean no colocalization, the values close to 3 mean a perfect colocalization. Representative images are shown from three independent experiments.

standard, a known inhibitor of acetylcholinesterase [24]. After short 5 min incubation of the cell lysate with GNDAs $(0.5 \mu \mathrm{M})$, a remaining $52-72 \%$ antiAChE activity was found (Fig. 5). Tacrine proved to be a more potent AChE inhibitor (only $30 \%$ remaining enzyme activity) than GNDAs but its inhibitory effect significantly decreased after extended $48 \mathrm{~h}$ incubation. Such a recovery of the AChE activity has not been observed after $48 \mathrm{~h}$ incubation of the cells with GNDAs.

Mechanism of the ACHE inhibition. To compare inhibitory effects of GNDAs and tacrine, kinetic data were analyzed using a double-reciprocal Lineweaver-Burk plot. Human erythrocyte acetylcholinesterase $\left(\mathrm{AChE}_{\mathrm{E}}\right)$ was used and a dose-dependent inhibition of the enzyme with GNDAs was 




Figure 5. The effect of GNDAs on AChE activity in SH-SY5Y cells. SH-SY5Y cells were incubated with $0.5 \mu M$ GNDAs or $0.5 \mu M$ tacrine for 48 h (non-cytotoxic concentrations), then the cells were harvested and ACHE activity was determined in the cell lysate as described in Methods. The inhibition effect was evaluated after short-time incubation; the substances were incubated with the cell lysate $\left(1 \times 10^{6} \mathrm{cells} / 0.1 \mathrm{~mL}\right)$ for $5 \mathrm{~min}$ and the enzyme activity was assayed. The results are presented as the mean $\pm \operatorname{SD}(n=3)$, statistical significance $p<0.001\left({ }^{* *}\right)$ for particular experimental group compared to untreated control.

estimated first. The concentration-response curves showed that these compounds inhibited AChE in a dose-dependent manner. Determined $\mathrm{IC}_{50}$ values proved that GNDA derivatives were less potent than tacrine (Table 2).

As can be seen in Fig. 6A, the double-reciprocal LineweaverBurk plot revealed that both slopes and intercepts increased with a higher pentyl-GNDA concentration, demonstrating thus a mixed-type competitive and non-competitive inhibition. The inhibition constant $K_{i}=0.4 \mu \mathrm{M}$ was obtained from a secondary plot of the slope versus the concentration of pentyl-GNDA (Fig. 6A; inset). Tacrine behaved as a mixedtype inhibitor (Fig. 6B) as indicated in articles $[25,26]$.

\section{Discussion}

Most of acridine compounds are cytotoxic and their toxicity is caused by their DNA binding activity and some of them thus can serve as probes for mutagenesis examination [15, 27-32]. In spite of that, cytotoxicity of some acridines may not be connected with their interaction with nuclear DNA but they could induce an ER stress or oxidative stress in cells. Such types of acridines were prepared in our laboratory [33-35]. It was proven that 3,6-bis((1-n-alkyl-5-oxo-imidazolidin-2-yliden) imino)acridine hydrochlorides were localized in mitochondria [36]. Likewise, unusual non-nuclear accumulation of 3-amino4-hydroxymethyl-acridine derivative in the form of aggregates in the cytoplasm accompanied by its localization also in lysosomes was found out by Peixoto et al. in 2009 [37].

Recently Plsikova et al. [16] has documented that novel derivatives of acridine, 3,6-bis(3-alkylguanidino)acridines
Table 2. In vitro inhibition effects of GNDAs and tacrine on $\mathrm{AChE}_{\mathrm{E}}$

\begin{tabular}{ll}
\hline Compound & $\mathrm{IC}_{50}[\mu \mathrm{M}]^{\mathrm{a}}$ \\
\hline pentyl-GNDA & $0.60 \pm 0.09$ \\
hexyl-GNDA & $1.60 \pm 0.19$ \\
tacrine & $0.23 \pm 0.02$ \\
\hline
\end{tabular}

a The results are presented as a mean $\pm \operatorname{SD}(n=3)$.

are effective DNA-intercalating agents, whose cytotoxic action is dependent mainly on their intracellular accumulation in nuclei of leukemia HL-60 cells. We have proceeded further with investigation of the cytotoxicity of GNDAs. Surprisingly, considerable cytotoxicity of the pentyl-and hexyl-GNDA (the most cytotoxic were GNDAs derivatives against HL-60 cells) was confirmed only against A2780 and NIH-3T3 cells, but not against SH-SY5Y neuroblastoma cells. It was shown that derivatives of GNDA were localized in nuclei of the A2780 and NIH3-T3 cells. But, the presence of the GNDA derivative in nuclei of SH-SY5Y cells was not proved. We have observed that GNDAs were accumulated at the plasma membrane of SH-SY5Y cells and surroundings.

We have searched for a potential cellular target for GNDAs in the SH-SY5Y cell line that is being used as a cellular model of cholinergic phenotype [38] with expression of acetylcholinesterase [39-41]. AChE is responsible for the termination of cholinergic transmission (breakdown of acetylcholine) [42, 43]. Two isoforms of $\mathrm{AChE}$ are synthesized in neuroblastoma cells, AChE-T (AChE-T, a tailed form of AChE) is linked to the 

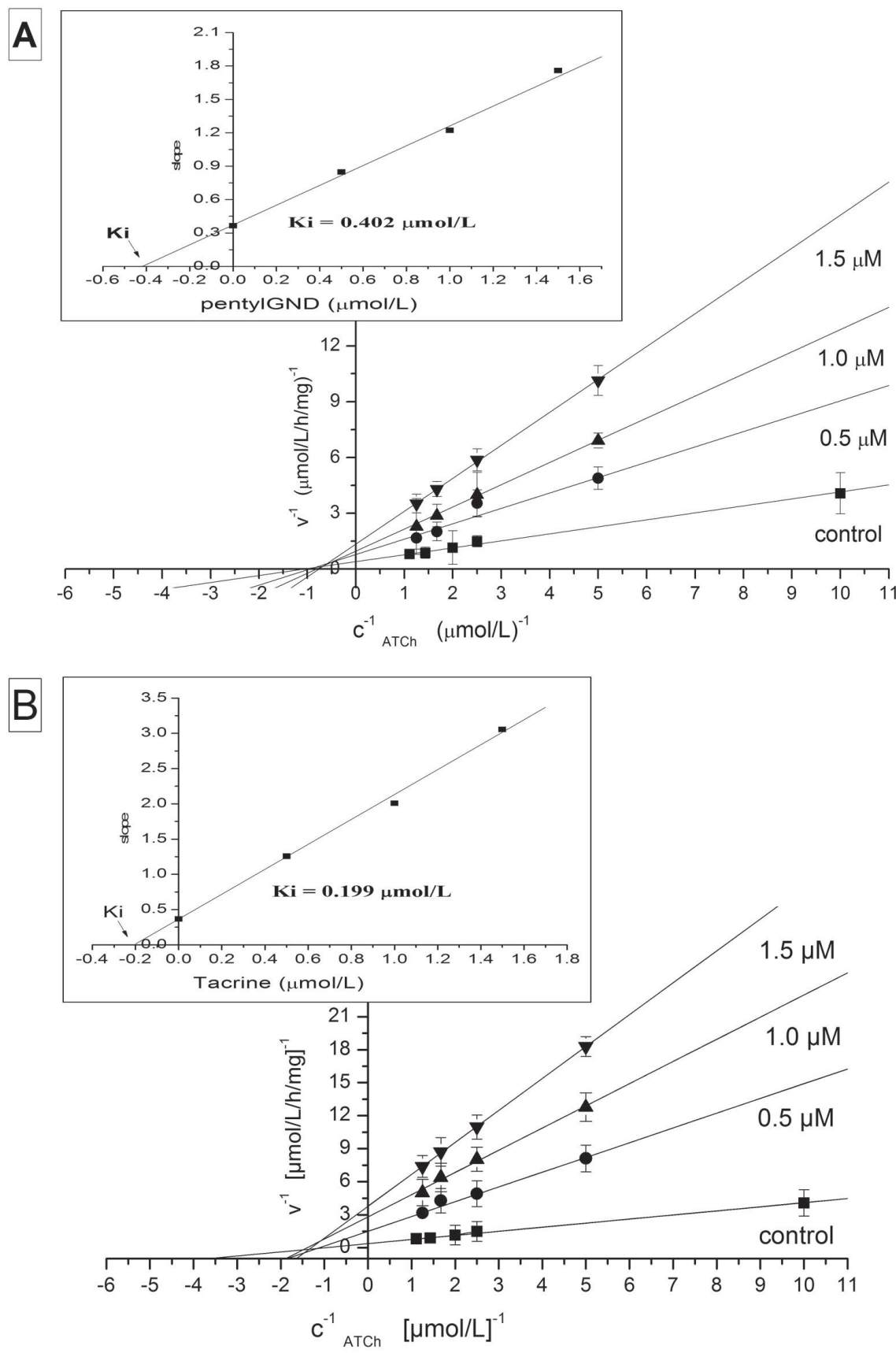

Figure 6. The inhibition of acetylcholinesterase by pentyl-GNDA and tacrine. Lineweaver-Burk plots representing reciprocals of initial enzyme velocity versus ATCh concentration in the absence and presence of different concentrations of pentyl-GNDA (A) and tacrine (B). Inset: Secondary replots of Lineweaver-Burk plot slope versus tacrine or GNDA concentrations. The data are expressed as the mean \pm SD $(n=3)$.

cellular membrane and its soluble splice variant, AChE-R, is realeased into the cell media [44-49]. Thus acetylcholinesterase has been proposed as a potential target.

Our study of the interaction between GNDAs and AChE confirmed that these derivatives of acridine were able to inhibit the AChE activity in SH-SY5Y cells. Kinetic analysis (AChE from human erythrocytes was used for this study) revealed that GNDAs were acting as the mixed-type AChE inhibitors as well as tacrine (9-amino-1,2,3,4-tetrahydroacridine), a known inhibitor of AChE that was the first AChEI introduced in the therapy of the Alzheimer's disease $[50,51]$. The effect of GNDAs on AChE in the SH-SY5Y cells was not the same 
as the action of tacrine. Although tacrine was more potent AChE inhibitor than GNDAs, its effect on AChE activity in the SH-SY5Y cells was only temporal. The inhibition of AChE by tacrine is known to elicit a feedback process that leads to expression of AChE [52-54]. The effect of GNDAs had longer duration and the AChE activity in SH-SY5Y cells remained reduced also after $48 \mathrm{~h}$.

Our results showed that explored 3,6-bis(3-alkylguanidino) acridines, the substances with high affinity to DNA, were cytotoxic against the cells A2780 and NIH-3T3. But, their cytotoxicity against neuroblastoma $\mathrm{SH}-\mathrm{Y} 5 \mathrm{Y}$ cells was very low probably due to their interaction with $\mathrm{AChE}$, which influenced their intracellular distribution, preventing GNDAs to reach the nucleus.

Acknowledgments: Financial support for this work was from the Grant Agency VEGA (Ministry of Education of the Slovak Republic, $1 / 0001 / 13 ; 1 / 0790 / 14 ; 2 / 0177 / 11,1 / 0936 / 14)$ and it is also the result of the project implementation: TRANSMED 2, ITMS: 26240120030, supported by the Research \& Development Operational Programme funded by the ERDF.

\section{References}

[1] MAZEVET M, MOULIN M, LLACH-MARTINEZ A, CHARGARI C, DEUTSCH E et al. Complications of chemotherapy, a basic science update. Presse Med 2013; 42: 352-361. http:// dx.doi.org/10.1016/j.lpm.2013.06.011

[2] FIKROVA P, STETINA R, HRNCIARIK M, REHACEK V, JOST P et al. Detection of DNA crosslinks in peripheral lymphocytes isolated from patients treated with platinum derivates using modified comet assay. Neoplasma 2013; 60: 413-418. http://dx.doi.org/10.4149/neo $2013 \quad 053$

[3] XING L, LU H, ZHANG J, YU J, WANG F et al. Phase I study of docetaxel, cisplatin and concurrent radiotherapy for locally advanced gastric adenocarcinoma. Neoplasma 2012, 59: 370-375. http://dx.doi.org/10.4149/neo $2012 \quad 048$

[4] OZKAN M, BERK V, KAPLAN MA, BENEKLI M, COSKUM $\mathrm{U}$ et al. Gemcitabine and cisplatin combination chemotherapy in triple negative metastatic breast cancer previously treated with a taxane/anthracycline chemotherapy; multicenter experience. Neoplasma 2012; 59: 38-42. http://dx.doi.org/10.4149/ neo 2012005

[5] ARIMONDO PB, BOUTORINE A, BALDEYROU B, BAILLY $\mathrm{C}$, KUWAHARA $\mathrm{M}$ et al. Design and optimization of camptothecin conjugates of triple helix-forming oligonucleotides for sequence-specific DNA cleavage by topoisomerase I. J Biol Chem 2002; 277: 3132-3140. http://dx.doi.org/10.1074/jbc. M110181200

[6] ARIMONDO PB, HELENE C Design of new anti-cancer agents based on topoisomerase poisons targeted to specific DNA sequences. Curr Med Chem Anticancer Agents 2001; 1: 219-235. http://dx.doi.org/10.2174/1568011013354642

[7] CASSILETH PA, GALE RP Amsacrine: A review. Leuk Res 1986; 10: 1257-1265. http://dx.doi.org/10.1016/01452126(86)90331-0
[8] KETRON AC, DENNY WA, GRAVES DE, OSHEROFF N. Amsacrine as a topoisomerase II poison: Importance of drugDNA interactions. Biochemistry 2012; 51: 1730-1739. http:// dx.doi.org/10.1021/bi201159b

[9] MARSH KL, WILLMORE E, TINELLI S, CORNAROTTI M, MECZES EL et al. Amsacrine-promoted DNA cleavage site determinants for the two human DNA topoisomerase II isoforms $\alpha$ and $\beta$. Biochem Pharmacol 1996; 52: 1675-1685. http://dx.doi.org/10.1016/S0006-2952(96)00516-3

[10] RAZA A, JACOBSON BA, BENOIT A, PATEL MR, JAY-DIX$\mathrm{ON} J$ et al. Novel acridine-based agents with topoisomerase II inhibitor activity suppress mesothelioma cell proliferation and induce apoptosis. Invest New Drugs 2012; 30: 1443-1448. http://dx.doi.org/10.1007/s10637-011-9720-7

[11] ANTONINI I, POLUCCI P, MAGNANO A, SPARAPANI S, MARTELLI S Rational design, synthesis, and biological evaluation of bis(pyrimido[5,6,1-de]acridines) and bis(pyrazolo[3,4,5-kl]acridine-5-carboxamides) as new anticancer agents. J Med Chem 2004; 47: 5244-5250. http:// dx.doi.org/10.1021/jm049706k

[12] BELMONT P, BOSSON J, GODET T, TIANO M Acridine and acridone derivatives, anticancer properties and synthetic methods: where are we now? Anticancer Agents Med Chem 2007; 7: 139-169. http://dx.doi.org/10.2174/187152007780058669

[13] CHILIN A, MARZARO G, MARZANO C, DALLA VL, FERLIN MG, et al. Synthesis and antitumor activity of novel amsacrine analogs: the critical role of the acridine moiety in determining their biological activity. Bioorg Med Chem 2009; 17: 523-529. http://dx.doi.org/10.1016/j. bmc.2008.11.072

[14] DA ROCHA PITTA MG, DE LIMA MD, GALDINO SL, DA ROCHA PITTA I Niche for acridine derivatives in anticancer therapy. Mini Rev Med Chem 2013; 13: 1256-1271. http:// dx.doi.org/10.2174/1389557511313090002

[15] BAJDICHOVA M, PAULIKOVA H, JAKUBIKOVA J, SABOLOVA D Comparison of inhibition of murine leukaemia cell growth by 9 -isothiocyanatoacridine and its cytosine adduct: involvement of thiols. Neoplasma 2007; 54: 463-470.

[16] PLSIKOVA J, JANOVEC L, KOVAL L, UNGVARSKY J, MIKES J et al. 3,6-Bis(3-alkylguanidino)acridines as DNAintercalating antitumor agents. Eur J Med Chem 2012; 57: 283-295. http://dx.doi.org/10.1016/j.ejmech.2012.09.020

[17] CIPAKL Novel nonclassical antifolate, 2-[N-(2'-Hydroxyethyl) amino]methyl-3H-quinazolin-4-one, with a potent antineoplastic activity toward leukemia cells. Neoplasma 2012; 59: 641-649. http://dx.doi.org/10.4149/neo 2012081

[18] ALJAFARI AA Kinetics for the inhibition of acetylcholinesterase from human erythrocyte by cisplatin. Int J Biochem Cell Biol 1995; 27: 965-970. http://dx.doi.org/10.1016/13572725(95)00044-P

[19] ELLMAN GL, COUNTER KD, ANDRES VJ, FEATHERSTONE RM A new and rapid colorimetric determination of acetylcholinesterase activity. Biochem Pharmacol 1961; 7: 88-95. http://dx.doi.org/10.1016/0006-2952(61)90145-9

[20] ALHOMIDA AS, AL-RAJHI AA, KAMAL MA, ALJAFARI AA Kinetic analysis of the toxicological effect of tacrine on human retinal acetylcholinesterase activity. 
Toxicology 2000; 147: 33-39. http://dx.doi.org/10.1016/ S0300-483X(00)00177-3

[21] EYER P, WOREK P, KIDERLEN D, SINKO G, STUGLIN A et al. Molar absorption coefficients for the reduced Ellman reagent: reassessment. Anal Biochem 2003; 312: 224-227. http://dx.doi.org/10.1016/S0003-2697(02)00506-7

[22] BRADFORD MM Rapid and sensitive method for the quantitation of microgram quantities of protein utilizing the principle of protein-dye binding. Anal Biochem 1976; 72: 248-254. http://dx.doi.org/10.1016/0003-2697(76)90527-3

[23] THULLBERY MD, COX HD, SCHULE T, THOMPSON CM, GEORGE KM DIFFERENTIAL Localization of Acetylcholinesterase in Neuronal and Non-Neuronal Cells. J Cell Biochem 2005; 96: 599-610. http://dx.doi.org/10.1002/ jcb. 20530

[24] FREEMAN SE, DAWSON RM TACRINE: A pharmacological review. Prog Neurobiol 1991; 36: 257-277. http://dx.doi. org/10.1016/0301-0082(91)90002-I

[25] AL-JAFARI AAJ The nature of the inhibition of cancel retina acetylcholinesterase (EC 3.1.1.7) activity by tetrahydroaminoacridine. J Ocul Pharmacol Ther 1996; 12: 503-514. http:// dx.doi.org/10.1089/jop.1996.12.503

[26] BERMAN HA, LEONARD K Interaction of tetrahydroaminoacridine with acetylcholinesterase and butyrylcholinesterase. Mol Pharmacol 1992; 41: 412-418.

[27] CHOLEWINSKI G, DZIERBICKA K, KOLODZIEJCZYK AM Natural and synthetic acridine/acridone as antitumor agents: Their biological activities and methods of synthesis. Pharmacol Rep 2011; 63: 305-336. http://dx.doi.org/10.1016/ S1734-1140(11)70499-6

[28] FIRTH WJ, ROCK SG, BROWN BR, YIELDING LW Azido analogs of acridine: Photoaffinity probes for frameshift mutagenesis in Salmonella typhimurium. Mutat Res 1981; 81: 295-309. http://dx.doi.org/10.1016/0027-5107(81)90118-4

[29] KOZURKOVA M, SABOLOVA D, JANOVEC L, MIKES J, KOVAL J et al. Cytotoxic activity of proflavine diureas: Synthesis, antitumor evaluation and DNA binding properties of 1',1"-(acridin-3,6-diyl)-3',3"-dialkyldiureas. Bioorg Med Chem 2008; 16: 3976-3984. http://dx.doi.org/10.1016/j. bmc.2008.01.026

[30] SZUMIEL I, WALICKA M Cytotoxicity and the effect of combined treatment with X-rays of an anticancer 1-nitro-9aminoacridine derivative in L5178Y-R and L5178Y-S cells. Neoplasma 1980; 27: 697-702.

[31] MIERTUS S, MAJEK P Correlations between quantum chemical indices and carcinogenicity of methylbenz(a)anthracenes, methylbenzacridines and their model metabolites. Neoplasma 1982; 29: 709-718.

[32] STUDZIAN K, TOLWINSKA-STANCZYK Z, WILMANSKA D, PALUMBO M, GNIAZDOWSKI M Crosslinking of cellular DNA by nitracrine and furocoumarin derivatives. Neoplasma 1999; 46: 50-53.

[33] JANOVECL, KOZURKOVA M, SABOLOVA D, UNGVARSKY J, PAULIKOVA $\mathrm{H}$ et al. Cytotoxic 3,6-bis((imidazolidinone) imino)acridines: Synthesis, DNA binding and molecular modeling. Bioorg Med Chem 2011; 19: 1790-1801. http:// dx.doi.org/10.1016/j.bmc.2011.01.012
[34] VANTOVA Z, PAUlikOVA H, SABOlOVA D, KOZURKOVA M, SUCHANOVA $M$ et al. Cytotoxic activity of acridin-3,6-diyl dithiourea hydrochlorides in human leukemia line HL-60 and resistant subline HL-60/ADR. Int J Biol Macromol 2009; 45: 174-180. http://dx.doi.org/10.1016/j. ijbiomac.2009.04.018

[35] PAULIKOVA H, VANTOVA Z, HUNAKOVA L, CIZEKOVA L, CARNA $M$ et al. DNA binding acridine-thiazolidinone agents affecting intracellular glutathione. Bioorg Med Chem 2012; 20: 7139-7148. http://dx.doi.org/10.1016/j.bmc.2012.09.068

[36] IPOTHOVA Z, PAULIKOVA H, HUNAKOVA M, JANOVEC J, IMRICH J et al. Subcellular localization of proflavine derivative and induction of oxidative stress-In vitro studies. Bioorg Med Chem 2013; 21: 6726-6731. http://dx.doi.org/10.1016/j. bmc.2013.08.007

[37] PEIXOTO P, ZEGHIDA W, CARREZ D, WU TD, WATTEZ $\mathrm{N}$ et al. Unusual cellular uptake of cytotoxic 4-hydroxymethyl3-aminoacridine. 2009; 44 : 4758-4763.

[38] HASHEMI SH, LI JY, AHLMAN H, DALSTROM A SSR2(a) receptor expression and adrenergic/cholinergic characteristics in differentiated SH-SY5Y cells. Neurochem Res 2003; 28: 449-460. http://dx.doi.org/10.1023/A:1022848718109

[39] HICKS DA, MAKOVA NZ, NALIVAEVA NN, TUNER AJ Hicks Characterization of acetylcholinesterase release from neuronal cells. Chem Biol Interact 2012; 203: 302-308. http:// dx.doi.org/10.1016/j.cbi.2012.09.019

[40] PERRIER AL, MASSOULIE J, KREJCI E PRiMA: the membrane anchor of acetylcholinesterase in the brain. Neuron 2002; 33: 275-285. http://dx.doi.org/10.1016/S08966273(01)00584-0

[41] THULLBERY MD, COX HD, SCHULE T, THOMPSON CM, GEORGE KM Differential localization of acetylcholinesterase in neuronal and non-neuronal cells. J Cell Biochem 2005; 96: 559-610. http://dx.doi.org/10.1002/jcb.20530

[42] RADIC Z, KIRCHHOFF PD, QUINN DM, MCCAMMON JA, TAYLOR P Elektrostatic influence on the kinetics of ligand-binding to acetylcholinesterase - distinctions between active-center ligands and fasciculin J Biol Chem 1997; 272: 23265 - 23277. http://dx.doi.org/10.1074/jbc.272.37.23265

[43] NAIR HK, SERVALLI J, ARBUCKLE T, QUINN DM Molecular Recognition in Acetylcholinesterase Catalysis: Free-Energy Correlations for Substrate Turnover and Inhibition by Trifluoro Ketone Transition-State Analogs. Biochemistry 1994; 33(28): 8566-8576. http://dx.doi.org/10.1021/bi00194a023

[44] MASSOUliE J, BON S, PERRIER N, FALASCA C The C-terminal peptides of acetylcholinesterase: Cellulartrafficking, oligomerization and functional anchoring. Chem Biol Interact 2005; 157-158: 3-14. http://dx.doi.org/10.1016/j. cbi.2005.10.002

[45] HARTL R, GLEINICH A, ZIMMERMAN M Dramatic increase in readthrough acetylcholinesterase in cellular model of oxidative stres. J Neurochem 2011; 116: 1088-1096. http:// dx.doi.org/10.1111/j.1471-4159.2010.07164.x

[46] ZIMMERMAN M Neuronal AChE splice variants and their non-hydrolytic functions: redefining a target of AChE inhibitors? Br J Pharmacol 2013; 170: 953-967. http://dx.doi. org/10.1111/bph.12359 
[47] TAYLOR P, RADIC $Z$ The cholinesterases: from genes to proteins. Annu Rev Pharmacol Toxicol 1994; 34: 281-320. http://dx.doi.org/10.1146/annurev.pa.34.040194.001433

[48] SOREQ H, SEIDMAN S Acetylcholinesterase - new roles for an old actor. Nat Rev Neurosci 2001; 2: 294-302. http://dx.doi. org/10.1038/35067589

[49] TOIBERD, BERSON A, GREENBERG D, MELAMED-BOOK N, DIAMANT $S$ et al. N-acetylcholinesterase-induced apoptosis in Alzheimer's disease. PLoS ONE 2008; 3: 3108 http:// dx.doi.org/10.1371/journal.pone.0003108

[50] ANAND P, SINGH B A review on cholinesterase inhibitors for Alzheimer's disease. Arch Pharm Res 2013; 36: 375-399. http://dx.doi.org/10.1007/s12272-013-0036-3

[51] KORABECNY J, SPILOVSKA K, BENEK O, MUSILEK $\mathrm{K}$, SOUKUP $\mathrm{O}$ et al. Tacrine and its derivatives in the therapy of Alzheimer's disease. Ceska Slov Farm 2012; 61: $210-221$.
[52] DARREH-SHORI T, HELLSTROM-LINDAHL E, FLORESFLORES C, GUAN ZZ, SOREQ H et al. Long-lasting acetylcholinesterase splice variations in anticholinesterasetreated Alzheimer's disease patients. J Neurochem 2004; 88: 1102-1113. http://dx.doi.org/10.1046/j.14714159.2003.02230.x

[53] DARREH-SHORI T, ALMKVIST O, GUAN ZZ, GARLIND A, STRANDBERG B et al. Sustained cholinesterase inhibition in $\mathrm{AD}$ patients receiving rivastigmine for 12 months. Neurology 2002; 59: 563-572. http://dx.doi.org/10.1212/ WNL.59.4.563

[54] GARCIA-AYLLON MS, SILVEYRA MX, ANDREASEN N, BRIMIJOIN S, BLENNOW K et al. Cerebrospinal fluid acetylcholinesterase changes after treatment with donepezil in patients with Alzheimer's disease. J Neurochem 2007; 101: 1701-1711. http://dx.doi.org/10.1111/j.14714159.2007.04461.x 